\title{
Multidrug resistance and high prevalence of class 1 integrons in Escherichia coli isolated from waters and vegetables in Nsukka and Enugu, Nigeria.
}

\author{
Chinyere B. Chigor ${ }^{1.2 \uparrow}$, Ini-Abasi I. Ibangha ${ }^{1,3 \&}$, Nkechinyere O. Nweze ${ }^{1.2 \uparrow,}$
} Chizoba A. Ozochi ${ }^{1,3 \pi}$, Valentino C. Onuora ${ }^{1,3 \&}$, Yinka Titilawo ${ }^{4 \pi}$, Tatyana N. Chernikova ${ }^{5 \pi}$, Peter N. Golyshin ${ }^{5}$ and Vincent N. Chigor ${ }^{1,3 *}$

${ }^{1}$ Water and Public Health Research Group (WPHRG), University of Nigeria, Nsukka, Enugu State, Nigeria.

${ }^{2}$ Department of Plant Science and Biotechnology, Faculty of Biological Sciences, University Nigeria, Nsukka, Enugu State, Nigeria.

${ }^{3}$ Department of Microbiology, Faculty of Biological Sciences, University of Nigeria, Nsukka, Enugu State, Nigeria.

${ }^{4}$ Department of Biology/Microbiology/Biotechnology, Alex Ekwueme Federal University, NdufuAlike Ikwo, Ebonyi State, Nigeria.

${ }^{5}$ School of Natural Sciences, Bangor University, Bangor Gwynedd, United Kingdom

*Corresponding author

E-mail: vincent.chigor@unn.edu.ng (VNC)

"VNC and PNG are Joint Senior Authors"

Keywords: multidrug resistance; Integrons; pathogenic E. coli; wastewater-irrigated vegetables; public health risks

Running title: Multidrug resistance and class 1 integrons in Escherichia coli 


\section{Abstract}

41 In spite of treated wastewater presenting itself as an attractive alternative to scarce quality water

42 in the developing countries, the associated contamination of fresh produce by irrigation waters

43 leading to outbreak of foodborne illnesses is on the rise. Horizontal transfer of integrons play important role in the spread and maintenance of antimicrobial resistance among strains of Escherichia coli. This study assessed the effluents from the University of Nigeria, Nsukka Wastewater Treatment Plant (UNN-WWTP) as well as vegetables irrigated with the effluent, and vegetables sold in selected markets from Nsukka and Enugu cities for the presence of $E$. coli and determined the prevalence integrons in multidrug-resistant isolates. Isolation of E. coli was done using eosin methylene blue agar and isolates subjected to Gram staining for identification of presumptive colonies. Confirmation of E. coli was achieved by polymerase chain reaction (PCR) technique, targeting beta-glucuronidase (uidA). Resistance to antibiotics was determined using the Bauer-Kirby disk diffusion assay and the Clinical and Laboratory Standard Institute criteria. Integrons were detected by multiplex PCR using primers specific for class 1 and 2 integrons. A total of $178 \mathrm{E}$. coli isolates were obtained from WWTP effluent (41), and vegetables from greenhouse (46), farms (55) and market (36). Multi-drug resistance was detected in all the isolates, ranging from five-drug resistance in a single isolate to 16-drug resistance patterns in two different isolates. Of the total isolates, class 1 integrons were abundantly detected in $175(98.3 \%)$ and class 2 in $5(2.8 \%)$. All the class 2 integrons were found in isolates that were positive for class 1 . The high detection of $E$. coli in the studied effluent and vegetables pose potential public health hazards heightened by observed multidrug resistance in all the isolates and the high prevalence of class 1 integron. It is concluded that the vegetable samples are significant reservoirs for potentially pathogenic E. coli. Therefore, vegetable irrigation farming with unsafe water should be discontinued, while appropriate improvement strategies to ensure compliance should be facilitated without further delay.

\section{Introduction}

67 Pathogenic Escherichia coli causes significant morbidity and mortality worldwide [1-3]. Reported risk factors in the developing countries and sub-Saharan African regions include poor hygiene, unsafe water, improper disposal of waste and faeces, and contaminated food, local beverages and vegetables [2, 4, 5]. Vegetables can become contaminated with pathogenic and commensal 
bacteria from animals and humans, during growth, harvesting, distribution, storage and processing [6]. Although the contamination of fresh produce by irrigation waters has led to outbreak of foodborne illnesses, yet treated wastewater presents itself as an attractive alternative to scarce quality water in the developing countries.

E. coli has been reported as an aetiological agent of diarrhoea in both the northern and southwestern parts of Nigeria [7-12]. In a study that detected E. coli in 119 (44.74\%) of 270 diarrhoeal stool samples in Enugu and Onitsha cities, south-eastern Nigeria [13], enterotoxigenic E. coli (ETEC) was reported as the second most prevalent pathotype $(21.57 \%)$ after enteropathogenic $E$. coli (EPEC) (49.02\%). Likewise, a study conducted in Nsukka, that involved watery stools, drinking water, and some fruits and vegetables collected during the rainy periods (between April and October) over 3 year sampling regime (1996 to 1998), [4] reported that enteropathogenic $E$. coli (EPEC) was detected in $9(1.8 \%)$ of 500 stool samples, whereas no enteric bacterial pathogen was isolated from the fruits and vegetables. There appears to be no reports on ETEC prevalence in humans and on irrigated vegetables in Nsukka.

Excessive and inappropriate usage of antimicrobials in preventing or treating human and veterinary bacterial infectious diseases has led to increased antimicrobial and multidrug resistance (MDR) and the risk of transmission of antibiotic resistant bacteria (ARB) and antibiotic resistant genes (ARGs) from one country to another is a growing global challenge. [14-16] Attention should be given to how anthropogenic activities might be causing evolution of antibiotic resistance in the environment [16], and studies have shown that waste water treatment plants form a significant reservoir of resistance genes and suggested that waste water disposal increases the reservoir of resistance determinants in the environment either by the addition of resistance genes or input of agents selective for resistant phenotypes [17].

Along with transposons and plasmids, integrons, genetic elements commonly found in bacterial genomes that allow efficient acquisition and expression of exogenous genes, are central in the dissemination of antibiotic resistance among Gram-negative bacteria $[18,19]$. Horizontal transfer of integrons have been shown to play important role in the spread and maintenance of antimicrobial resistance among strains of $E$. coli and ARB can be transferred across borders by human travelers, animal and insect vectors, agricultural products and surface water $[15,20]$. Not much is known about the risk factors in spreading across local borders. 
101

102

103

104

105

106

107

108

109

110

111

112

113

114

115

116

117

118

119

120

121

122

123

124

125

126

127

128

129

It is thought that University towns, characterized by regular and significant demographic changes arising from admissions and vacations, could play major role in dissemination of resistance determinants locally, and even internationally where the institution has a good number of internationals. Nsukka, in Southeast Nigeria, is the location of one of Nigeria's biggest universities and one also in which the town developed around the university. This study assessed the effluent from the University of Nigeria, Nsukka Wastewater Treatment Plant (UNN-WWTP) as well as vegetables irrigated with the effluent and vegetables sold in selected markets for the presence of $E$. coli and determined the prevalence integrons in multidrug-resistant isolates.

\section{Methods}

\section{Description of study area}

The university town of Nsukka $\left(6.8429^{\circ} \mathrm{N}, 7.3733^{\circ}\right.$ E) is in Enugu State, southeast Nigeria, with an area of $1,810 \mathrm{~km}^{2}$ and a population of 309,633 (NPC 2006). The sewage treatment facility (WWTP) in Nsukka, consisting of a screen, primary settling (Imhoff) tank, sludge drying beds and two oxidation ponds, is situated at the northwest end of the University of Nigeria, Nsukka. The final effluents have been widely utilized for fresh produce irrigation during dry season.

\section{Cultivation of Amaranthus in the greenhouse}

The most commonly cultivated vegetables in the study area, during the dry season, include the green leafy vegetable amaranth (Amaranthus spp), fluted pumpkin leaves (Telfaria occidentalis), scarlet eggplant leaf (Solanum aethiopicum) and water leaf (Talinum fruticosum). In this study, Amaranthus was chosen, being the second most produced and sold leafy vegetable, after Telfaria [21], and it eqaully grows very easily and matures faster. Amaranths were grown for 10 weeks (July 26 to October 03, 2014) in earthen pots at the Soil Science Departmental greenhouse. They were irrigated daily using the sprinkler method. A total of 60 earthen pots were used for the cultivation of vegetables, 48 were irrigated with treated wastewater (final effluent of the University of Nigeria, wastewater treatment plant (WWTP) and 12 with tap water. The pots irrigated with tap water served as the control. 


\section{Collection of Samples}

Samples collected for this study included treated wastewater and vegetables. Sampling was done according to the standard procedure [22]. Effluents were collected with $10 \mathrm{~L}$ plastic cans for irrigation of the green house vegetables. Samples of the WWTP effluent were collected using sterile wide-mouthed, screw-capped 250-ml bottles. Vegetables were obtained from the green house, irrigated gardens and local markets in Nsukka and Enugu metropolis, during December 2014. Samples of the major vegetables cultivated during the dry season include fluted pumpkin leaves (Telfaria occidentalis), scarlet eggplant leaf (Solanum aethiopicum), water leaf (Talinum fruticosum) and the green vegetable (Amaranthus Spp) were collected. All samples were transported on ice to the laboratory and analysed within $6 \mathrm{~h}$ of collection.

\section{Isolation and identification of presumptive $E$. coli}

This was carried out at the Water and Public Health Laboratory, University of Nigeria Nsukka. Exactly $5 \mathrm{~g}$ of each vegetable sample was homogenized in a clean porcelain mortar, and $1 \mathrm{~g}$ of the homogenate diluted into $9 \mathrm{ml}$ normal saline $[23,24]$. Serial dilutions (10-fold) were made by pipetting out $1 \mathrm{ml}$ stock solution into successive $9 \mathrm{ml}$ of sterile normal saline bottles. A $1 \mathrm{ml}$ working sample dilution $\left(10^{-1}\right.$ and $\left.10^{-2}\right)$ was spread-plated onto eosin methylene blue (EMB) agar (Oxoid, UK), incubated at $44{ }^{\circ} \mathrm{C}$ for $18-24 \mathrm{~h}$. Raised, entire colonies with dark greenish metallic sheen, typical E. coli colonies were subjected to Gram-staining [25] and standard biochemical tests (IMViC). All presumptive E. coli isolates were sub-cultured in tryptic soy broth (Oxoid, UK) and then stored at $-20{ }^{\circ} \mathrm{C}$ for further investigations. All media were prepared following the manufacturers' instructions.

\section{Extraction of genomic DNA}

Genomic DNA were extracted from a pure culture of each isolate grown overnight on nutrient agar at $37^{\circ} \mathrm{C}$, by the conventional boiling method, as described [28]. Briefly, one loopful of bacterial cells was suspended in $1 \mathrm{ml}$ of sterile distilled water. The bacterial suspensions were then heated for $5 \mathrm{~min}$ at $100^{\circ} \mathrm{C}$, cooled to room temperature and centrifuged at 12,000 xg for $5 \mathrm{~min}$ to remove the debris. The supernatant was stored at $-20^{\circ} \mathrm{C}$ and used as the template DNA for PCR analysis. 
158

159

160

161

162

163

164

165

166

167

168

169

170

171

172

173

174

175

176

177

178

179

180

181

182

183

184

185

186

187

188

\section{Detection of beta-glucuronidase (uidA) gene for confirmation of $E$. coli}

The confirmation of $E$. coli was achieved by polymerase chain reaction (PCR) detection of the target beta-glucuronidase (uidA). This was done at the School of Natural Sciences, Bangor University, United Kingdom, following the procedures described [29, 30]. The extracted DNA were cleaned using QIAGEN (QIAEX $\left.{ }^{\circledR} I I\right)$ gel extraction kits and kept at -20 ${ }^{\circ}$. PCRs were carried out with BIORAD DNA Engine Tetrad®Peltier Thermal Cycler (BIORAD, USA). The PCR reaction mixtures consisted of $25 \mu$ of PCR Master Mix (Thermo Scientific, (EU) Lithuania), 0.5 $\mu \mathrm{l}$ each of oligonucleotide primers (Eurofins Genomics, Ebersberg Germany), $10 \mu \mathrm{l}$ of template DNA and $14 \mu \mathrm{l}$ of nuclease free water to constitute a total reaction volume of $50 \mu \mathrm{l}$. The PCR cycling conditions, with some modifications, were in accordance with the protocols prescribed elsewhere [31]. E. coli strain (NCTC 13353) and Enterobacter aerogenes (NCTC 10006) were used as positive and negative controls respectively for $E$. coli genus identification. The oligonucleotide sequence of primers used, target genes and expected amplification products are given in Table 1. For gel electrophoresis, $3 \mu 1$ of DNA ladder (1 Kb Plus DNA Ladder; Invitrogen), $6 \mu 1$ of positive control and $10 \mu 1$ of template DNA were ran on $2.5 \%(\mathrm{w} / \mathrm{v})$ agarose gels in $1 \mathrm{x}-\mathrm{TBE}$ buffer (0.09 M Tris-borate and 0.002 M EDTA, $\mathrm{pH} 8.0$ ) at $100 \mathrm{~V}$ for 25-30 min. The gels were viewed and photographed with BIORAD Molecular Imager ${ }^{\circledR}$ Gel Doc ${ }^{\mathrm{TM}}$ XR Imaging System (BIORAD, USA).

\section{Antibiotic susceptibility testing}

Isolates were subjected to antibiotic susceptibility testing using the Kirby-Bauer disc diffusion test [26]. Evaluation of results was based on the standards of the Clinical Laboratory Standards Institute (CLSI) [27]. Briefly, isolates grown on nutrient broth were suspended into sterile normal saline $(0.9 \%(\mathrm{w} / \mathrm{v}) \mathrm{NaCl})$ with the aid of a sterile wire loop until the turbidity equivalent of $0.5 \mathrm{McFarland}$ standard was reached. Sterile non-toxic cotton swabs were dipped into the standardized inoculum and used to smear the entire surface of the Muller-Hinton agar (Thermo Fisher Scientific, USA) plates. Antibiotic discs were placed aseptically using sterile forceps. All plates were incubated at $35 \pm 2 \mathrm{oC}$ for 16 to $18 \mathrm{~h}$. The following antibiotics were

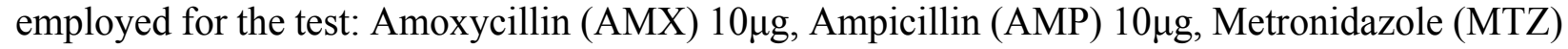

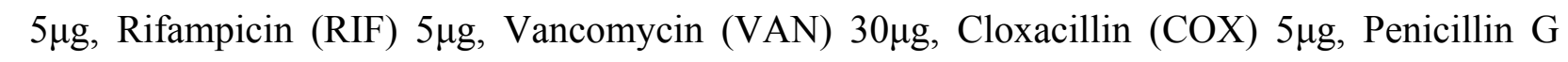






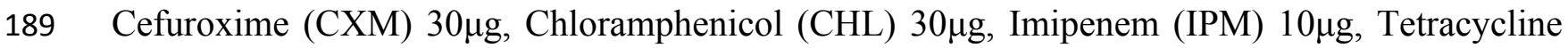



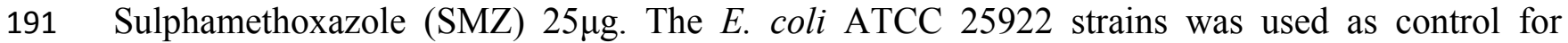
192 antibiotic susceptibility testing. Zones showing complete inhibition around the discs were 193 measured and classified as resistant (R), intermediate (I) and susceptible (S) according to the 194 diameters of the zones recorded to the nearest millimetres.

\section{Detection of integrons}

The isolates were screened for class 1,2 and 3 integrons by a multiplex PCR procedure as 197 described by Machado et al. [32] and Karger et al. [33]. The PCR reactions (a total volume of 50 $\mu 1$ 198 reaction mixture) each consisted of consisting of $10 \mu \mathrm{l}$ Buffer of 5x MyTaq Reaction Buffer 199 (Bioline, with dye), $0.75 \mu \mathrm{l}$ of each the primers int $\mathrm{1} 1$, int $\mathrm{I} 2$ and int $\mathrm{I} 3$ (Eurofins Genomics,


201 polymerase (Bioline) and $5 \mu \mathrm{l}$ DNA template. For gel electrophoresis, $3 \mu 1$ of DNA ladder $(1 \mathrm{~Kb}$ 202 Plus DNA Ladder; Invitrogen), $6 \mu 1$ of positive control and $10 \mu 1$ of samples were ran on $1.5 \%$ $203(\mathrm{w} / \mathrm{v})$ agarose gels in 1x-TBE buffer (0.09 M Tris-borate and 0.002 M EDTA, pH 8.0) at $100 \mathrm{~V}$ 204 for $25 \mathrm{~min}$. The gels were viewed and photographed with BIORAD Molecular Imager® Gel Doc ${ }^{\mathrm{TM}}$ 205 XR Imaging System. 
Table 1: Primers for the detection of $E$. coli and integrons

\begin{tabular}{|c|c|c|c|c|c|}
\hline Genetic & Primer ns & and sequence (5' to 3') & Amplicon & Thermocycling conditions & Reference \\
\hline $\begin{array}{l}\text { uidA } \\
\text { (beta- } \\
\text { glucuronidase) }\end{array}$ & $\begin{array}{l}\text { UAL-754 } \\
\text { UAR-900 }\end{array}$ & $\begin{array}{l}\text { AAAACGGCAAGAAAAAGCAG } \\
\text { ACGCGTGGTTACAGTCTTGCG }\end{array}$ & 147 & $\begin{array}{l}\text { Initial activation at } 95^{\circ} \mathrm{C} \text { for } 3 \mathrm{~min} \text {, followed by } \\
40 \text { cycles consisting of denaturing at } 94^{\circ} \mathrm{C} \text { for } 1 \\
\text { min, annealing at } 65^{\circ} \mathrm{C} \text { for } 1 \mathrm{~min} \text {, extension at } \\
70^{\circ} \mathrm{C} \text { for } 1 \mathrm{~min} \text { and final elongation at } 72^{\circ} \mathrm{C} \text { for } 7 \\
\text { min }\end{array}$ & {$[29,30]$} \\
\hline $\begin{array}{l}\text { int } \mathrm{I} 1 \text { (Class } 1 \\
\text { integron) }\end{array}$ & $\begin{array}{l}\text { Int } 1-\mathrm{F} \\
\text { Int1-R }\end{array}$ & $\begin{array}{l}\text { GGTCAAGGATCTGGATTTCG } \\
\text { ACATGCGTGTAAATCATCGTC }\end{array}$ & 436 & $\begin{array}{l}\text { Initial activation step at } 94^{\circ} \mathrm{C} \text { for } 5 \mathrm{~min} \text {, followed } \\
\text { by } 32 \text { cycles consisting of denaturing at } 94^{\circ} \mathrm{C} \text { for } \\
1 \mathrm{~min} \text {, annealing at } 60^{\circ} \mathrm{C} \text { for } 1 \mathrm{~min} \text {, extension at }\end{array}$ & {$[32,33]$} \\
\hline $\begin{array}{l}\text { int } 12 \text { (Class } 2 \\
\text { integron) }\end{array}$ & $\begin{array}{l}\text { Int2-F } \\
\text { Int2-R }\end{array}$ & $\begin{array}{l}\text { CACGGATATGCGACAAAAAGGT } \\
\text { GTAGCAAACGAGTGACGAAATG }\end{array}$ & 788 & $\begin{array}{l}72^{\circ} \mathrm{C} \text { for } 2 \mathrm{~min} \text { and final elongation at } 72^{\circ} \mathrm{C} \text { for } \\
10 \mathrm{~min}\end{array}$ & \\
\hline $\begin{array}{l}\text { int } \mathrm{I} 3 \text { (Class } 3 \\
\text { integron) }\end{array}$ & $\begin{array}{l}\text { Int3-F } \\
\text { Int3-R }\end{array}$ & $\begin{array}{l}\text { AGTGGGTGGCGAATGAGTG } \\
\text { TGTTCTTGTATCGGCAGGTG }\end{array}$ & 600 & & \\
\hline
\end{tabular}




\section{Results and Discussion}

212 It is worthy of note the amaranths irrigated with wastewater effluent were of higher yields

213 compared to the controls irrigated with tap water. This is attributable to the fact the effluent is rich

214 in nutrients. It also underscores the continued preference of effluents over the scarce treated water

215 by the vegetable farmers. Despite a perceived understanding farmer have on the use of unsafe

216 WWTP effluent, this knowledge seems not bother them.

219 were confirmed by PCR amplification of the $\beta$-glucuronidase uidA gene (Fig 1), with 41 isolates

220 from the WWTP effluents, 46 greenhouse from the effluent irrigated vegetables, 55 from 221 vegetables collected from gardens that produce vegetables sold in local markets and 36 from 222 vegetables bought from selected markets in Nsukka and Enugu (Table 2).

Fig 1. PCR products for $E$. coli confirmation by uidA gene amplification.

225 This is the Fig 1 legend: M: Molecular weight marker $(1 \mathrm{~KB})$, W: water, NC: Negative control 226 (Enterobacter aerogenes), PC: Positive control (E. coli; NCTC 13353), Lanes 1-15: Positive 227 isolates

Table 2: Isolation of $E$. coli in effluent wastewater and vegetable samples.

230

\begin{tabular}{lll}
\hline Sample type & No. of samples & $\begin{array}{l}\text { No. of } \boldsymbol{E} . \text { coli } \\
\text { isolates }\end{array}$ \\
\hline & & \\
\hline WWTP effluent & 60 & 41 \\
Greenhouse vegetables & 60 & 46 \\
Farm vegetables & 84 & 55 \\
Market Vegetables & 84 & 36 \\
Total & $\mathbf{2 8 8}$ & $\mathbf{1 7 8}$ \\
\hline
\end{tabular}


Table 3 shows the antibiotics susceptibility profiles of the $178 \mathrm{E}$. coli isolates tested with

23318 different antibiotics. Generally, higher resistance percentages were observed in E. coli from

234 market vegetables compared with others. This could be attributable to further contamination of 235 vegetables by clinical E. coli strains arising directly from handling by sellers. All the E. coli 236 isolates, showed susceptibility to imipenem and only 5.6\% (10/178) of all the isolates were 237 resistant to cefuroxime (a cephalosporin). Chloramphenicol, ciprofloxacin and norfloxacin were 238 very effective. The most significant resistance phenotypes were detected among 239 sulphamethoxazole (58.4\%), amoxicillin (52.8\%), tetracycline (47.2\%), trimethoprim (44.9\%) and 240 streptomycin (37.1\%), as these antibiotics are commonly used in the studied communities (Table $2412)$. 


\begin{tabular}{|c|c|c|c|c|c|c|c|c|}
\hline \multirow[t]{2}{*}{$\mathrm{S} / \mathrm{N}$} & \multirow{2}{*}{$\begin{array}{l}\text { Antimicrobial Agent } \\
\text { (disc concentration) }\end{array}$} & \multirow[t]{2}{*}{ Class (Subclasses) } & \multirow[t]{2}{*}{ Code } & \multicolumn{5}{|c|}{ Number of isolates resistant (\%) } \\
\hline & & & & $\begin{array}{l}\text { Effluent } \\
(\mathrm{n}=41)\end{array}$ & $\begin{array}{l}\text { Greenhouse } \\
(\mathrm{n}=46)\end{array}$ & $\begin{array}{l}\text { Farm } \\
(\mathrm{n}=55\end{array}$ & $\begin{array}{l}\text { Market } \\
(\mathrm{n}=36)\end{array}$ & $\begin{array}{l}\text { TOTAL } \\
(\mathrm{n}=178)\end{array}$ \\
\hline 1 & Cloxacillin $(5 \mu \mathrm{g})$ & $\beta$-Lactam (Penicillins) & $\mathrm{COX}$ & $41(100)$ & $46(100)$ & $55(100)$ & $36(100)$ & $178(100)$ \\
\hline 2 & Metronidazole $(50 \mu \mathrm{g})$ & Nitroimidazoles & MTZ & $41(100)$ & $46(100)$ & $55(100)$ & $36(100)$ & $178(100)$ \\
\hline 3 & Vancomycin $(30 \mu \mathrm{g})$ & Glycopeptides & VAN & $41(100)$ & $46(100)$ & $53(96.4)$ & $36(100)$ & $176(98.9)$ \\
\hline 4 & Rifampicin $(5 \mu \mathrm{g})$ & Rifamycins & RIF & $41(100)$ & $45(97.8)$ & $52(94.6)$ & $34(94.4)$ & $172(96.6)$ \\
\hline 5 & Penicillin (10U) & $\beta$-Lactam (Penicillins) & PNG & $39(95.1)$ & $45(97.8)$ & $54(98.2)$ & $34(94.4)$ & $172(96.6)$ \\
\hline 6 & Erythromycin $(15 \mu \mathrm{g})$ & Macrolides & ERT & $40(97.6)$ & $46(100)$ & $50(90.9)$ & $32(88.9)$ & $168(94.4)$ \\
\hline 7 & Clarithromycin $(15 \mu \mathrm{g})$ & Macrolides & CLR & $40(97.6)$ & $37(80.4)$ & $47(85.5)$ & $36(100)$ & $160(89.9)$ \\
\hline 8 & Ampicillin $(5 \mu \mathrm{g})$ & $\beta$-Lactam (Cephalosporins) & AMP & $34(82.9)$ & $38(82.6)$ & $50(90.9)$ & $36(100)$ & $158(88.7)$ \\
\hline 9 & Sulphamethoxazole $(25 \mu \mathrm{g})$ & Sulphonamides & $\mathrm{SMZ}$ & $23(56.1)$ & $27(58.7)$ & $26(47.3)$ & $28(77.8)$ & $104(58.4)$ \\
\hline 10 & Amoxicillin $(10 \mu \mathrm{g})$ & $\beta$-Lactam (Penicillins) & AMX & $23(56.1)$ & $24(52.2)$ & $26(47.3)$ & $21(58.3)$ & $94(52.8)$ \\
\hline 11 & Tetracycline $(30 \mu \mathrm{g})$ & Tetracyclines & TET & $25(61.0)$ & $20(43.5)$ & $16(29.1)$ & $23(63.9)$ & $84(47.2)$ \\
\hline 12 & Trimethoprim $(5 \mu \mathrm{g})$ & $\begin{array}{l}\text { Dihydrofolate Reductase } \\
\text { (DHFR \} inhibitors }\end{array}$ & TMP & $27(65.9)$ & $20(43.5)$ & $12(21.8)$ & $21(58.3)$ & $80(44.9)$ \\
\hline 13 & Streptomycin $(10 \mu \mathrm{g})$ & Aminoglycosides & STR & $15(36.6)$ & $21(45.7)$ & $16(29.1)$ & $14(38.9)$ & $66(37.1)$ \\
\hline 14 & Chloramphenicol $(30 \mu \mathrm{g})$ & Phenicols & CHL & $4(9.8)$ & $6(13.0)$ & $6(10.9)$ & $9(25.0)$ & $25(14.0)$ \\
\hline 15 & Ciprofloxacin $(5 \mu \mathrm{g})$ & Fluoroquinolones & CIP & $5(12.2)$ & $7(15.2)$ & $6(10.9)$ & $7(19.4)$ & $25(14.0)$ \\
\hline 16 & Norfloxacin $(10 \mu \mathrm{g})$ & Fluoroquinolones & NOR & $2(4.9)$ & $7(15.2)$ & $9(16.4)$ & $5(13.9)$ & $23(12.9)$ \\
\hline 17 & Cefuroxime $(30 \mu \mathrm{g})$ & $\beta$-Lactam (Cephalosporins) & CXM & $2(4.9)$ & $2(4.4)$ & $2(3.6)$ & $4(11.1)$ & $10(5.6)$ \\
\hline 18 & Imipenem $(10 \mu \mathrm{g})$ & $\beta$-Lactam (Carbapenems) & IMP & $0(0.0)$ & $0(0.0)$ & $0(0.0)$ & $0(0.0)$ & $0(0.0)$ \\
\hline
\end{tabular}


Multidrug resistance (MDR) has been frequently reported in Nigeria among E. coli isolates

265

266

267

268

269

270

271

272

273

274

275

276

277

278

279

280

281

282

283

284

285

286

287

288

289

290

291 obtained from human specimens [12, 37, 42, 43], animal sources [36] and environmental samples $[38,42,44,45]$. In the present study, all the isolates were multidrug resistant, ranging from 5-drug to 16-drug resistance patterns. Although some studies have reported a high removal efficiency for total ARGs in wastewater [46], our data suggest that sewage treatment process at UNN is not effective in reducing ARGs as all the Ecoli isolated from the effluent were MDR. The spread of AMR often limits the availability of therapeutic options to only a very few efficacious antibiotics [47]. The last-resort drugs, the carbapenems such as imipenem (used in this study) and meropenem, are themselves not only increasingly challenged by emerging resistance, as evident from the data presented here, but are not affordable in the developing regions.

Multidrug resistance (MDR) was detected in all E. coli isolates, and although this study did not determine the full virulence potentials of all the isolates subjected to antimicrobial susceptibility testing (AST), irrigational use of WWTP effluent represents a pathway for human exposure to antibiotic-resistant commensal and pathogenic bacteria. Vegetable farming at the site should therefore be discontinued as it presents significant threat to the health of consumers of such vegetables.

It is known that AMR and MDR in E. coli are acquired by the transfer of mobile genetic elements, such as plasmids, transposons and integrons [15, 18, 20]. In the present study, of the 178 E. coli isolates, class 1 integrons were detected (Fig 2) in 175 (98.3\%), and class 2 in 5 (2.8\%). All the class 2 integrons were found in isolates that were positive for class 1. Such co-carriage has been previously published on E. coli from meat turkeys in Italy, [34].

\section{Fig 2. Multiplex PCR products for detection of class 1 and 2 integrons}

This is the Fig 2 legend: M: Molecular weight marker (1 KB Plus ladder), W: water, Lanes 1-15: E. coli isolates

The integron carriage rate for the 137 vegetable isolates was $97.8 \%$, whereas the rate for 41 effluent isolates was $100 \%$. Considering that all the isolates were MDR, the detected high 
292

293

294

295

296

297

298

299

300

301

302

303

304

305

306

307

308

309

310

311

312

prevalence of class 1 integron is not surprising and compares with a previous study that reported that MDR phenotypes were observed in $96.8 \%$ of the integron-positive isolates [35]. These rates portend serious public health risks as it is known that class 1 integron could carry diverse antibiotic resistance genes (ARGs) and conduct horizontal gene transfer among microorganisms [20].

The data presented here shows that class 2 integrons were less frequently detected 5 (2.8\%). Similar data have been published for Enterobacteriaceae in Nigeria [36, 38] and elsewhere [34, 39, 40]. Ramírez et al [39], reported that unlike the widespread distribution of class 1 integron within Gram-negative bacilli, only Acinetobacter baumannii and Enterobacter cloacae harboured class 2 integrons at a high frequency. However, in an earlier study in China [41], Class 2 integrons were present in $25(80.6 \%)$ of the Shigella sonnei isolates and $29(87.9 \%)$ of the S. flexneri isolates whereas class 1 integrons were found in only 6 (9.4\%) of Shigella spp. isolates.

\section{Conclusions}

The present study revealed high detection of $E$. coli in the studied effluent and vegetable samples and represent potential public health hazards intensified by observed multidrug resistance in all the isolates and the high occurrence of class 1 integrons. It is concluded that UNN-WWTP is a significant reservoir for diarrheagenic E. coli. Vegetable farming at the site should therefore be discouraged as it presents significant threat to the health of consumers of such vegetables.

\section{Acknowledgments}

The authors are also grateful to Mr. Uchenna Oyeagu of the Water and Public Health Laboratory, University of Nigeria, Nsukka, Nigeria, for laboratory assistance.

\section{References}

1. Stacy-Phipps S, Mecca JJ, Weiss JB (1995) Multiplex PCR Assay and Simple Preparation Method for Stool Specimens Detect Enterotoxigenic Escherichia coli DNA during Course of Infection. J Clin Microbiol 33: 1054-1059.

2. Okeke IN (2009) Diarrheagenic Escherichia coli in sub-Saharan Africa: status, uncertainties and necessities. J Infect Dev Ctries 3: 817-842.

3. Brown JW, Badahdah A, Iticovici M, Vickers TJ, Alvarado DM, Helmerhorst EJ, Oppenheim FG, Mills JC, Ciorba MA, Fleckenstein JM. Bullitt E (2018) A Role for 
Salivary Peptides in the Innate Defense Against Enterotoxigenic Escherichia coli J Infect Dis. 217:1435-1441

4. Nzeako B, Okafor N (2002) Bacterial enteropathogens and factors associated with seasonal episodes of gastroenteritis in Nsukka, Nigeria. Br J Biomed Sci 59: 76-79.

5. WHO/UNICEF [World Health Organization and the United Nations Children's Fund] (2017). Progress on drinking water, sanitation and hygiene: 2017 update and SDG baselines. Geneva; 2017. Licence: CC BY-NC-SA 3.0 IGO.

6. FAO/WHO [Food and Agriculture Organization of the United Nations and World Health Organization]. (2008). Microbiological hazards in fresh leafy vegetables and herbs: Meeting Report. Microbiological Risk Assessment Series No. 14. Rome. 151pp.

7. Ogunsanya TL, Rotimi VO, Adenuga A (1994) Study of the aetiological agents of childhood diarrhoea in Lagos Nigeria. J Med Microbiol 40: 10-14.

8. Okeke IN, Fayinka ST, Lamikanra A (2000) Antibiotic Resistance in Escherichia coli from Nigerian Students, 1986-1998. Emerg Infect Dis 6: 393-396.

9. Olorunshola ID, Smith SI, Coker AO (2000) Prevalence of EHEC O157: H7 in patients with diarrhea in Lagos, Nigeria APMIS 108: 761-763.

10. Okeke IN, Steinruck H, Kanack KJ, Elliott SJ, Sundstrom L, Kaper JB, Lamikanra A (2002) Antibiotic-resistant cell-detaching Escherichia coli strains from Nigerian children. J Clin Microbiol 40: 301-305.

11. Chigor VN, Umoh VJ, Smith SI, Igbinosa EO, Okoh AI (2010) Multidrug resistance and plasmid patterns of Escherichia coli $\mathrm{O} 157$ and other E. coli isolated from diarrhoeal stools and surface waters from some selected sources in Zaria, Nigeria. Int J Environ Res Public Health 7: 3831-3841.

12. Onanuga A, Igbeneghu O, Lamikanra A (2014) A study of the prevalence of diarrhoeagenic Escherichia coli in children from Gwagwalada, Federal Capital Territory, Nigeria. Pan Afr Med J 17: 146.

13. Nweze EI (2010) Aetiology of Diarrhoea and Virulence Properties of Diarrhoeagenic Escherichia coli among Patients and Healthy Subjects in Southeast Nigeria. J Health Popul Nutr 28:245-252.

14. Okeke IN, Edelman R (2001) Dissemination of antibiotic-resistant bacteria across geographic borders. CID 33: 363-369.

15. Gaze WH, Zhang L, Abdouslam NA, Hawkey PM, Calvo-Bado L, Royle J, Brown H, Davis S, Kay P, Boxall ABA, Wellington EMH (2011) Impacts of anthropogenic activity on the ecology of class 1 integrons and integron-associated genes in the environment. The ISME J 5: 1253-1261.

16. Wellington EMH, Boxall ABA, Cross P, Feil EJ, Gaze WH, Hawkey PM, JohnsonRollings AS, Jones DL, Lee NM, Otten W, Thomas CM, Williams AP (2013) The role of the natural environment in the emergence of antibiotic resistance in Gram-negative bacteria. Lancet Infect Dis 13: 155-165.

17. Amos GCA, Zhang L, Hawkey PM, Gaze WH, Wellington EM (2014) Functional metagenomic analysis reveals rivers are a reservoir for diverse antibiotic resistance genes. Vet Microbiol 171: 441-447.

18. Gillings MR (2014) Integrons: Past, Present, and Future. Microbiol Mol Biol Rev 78: 257277. 
19. Strugeon E, Tilloy V, Ploy MC, Da Re S (2016) The stringent response promotes antibiotic resistance dissemination by regulating integron integrase expression in biofilms. mBio 7(4):e00868-16.

20. Ma L, Li AD, Yin XL, Zhang T (2017) The Prevalence of Integrons as the Carrier of Antibiotic Resistance Genes in Natural and Man-Made Environments. Environ Sci Technol 51: 5721-5728.

21. Asadu A, Enwelu I, Ifejika P, Igbokwe E (2016) Urban crop production in southeast Nigeria: Potentials and constraints. Afr J Agric Res 11: 4646-4653.

22. American Public Health Association (APHA) (2005). Standard Methods for the Examination of Water and Wastewater. 21st Edn. American Public Health Association, American Water Works Association, Water Environment Federation, Washington DC, USA.

23. Falomir MP, Gozalbo D, Rico H (2010) Coliform bacteria in fresh vegetables: from cultivated lands to consumers. In: A. Mandez-Vilas (Ed.). Current Research, Technology and Education Topics in Applied Microbiology and Microbial Biotechnology. FORMATEX; Badajoz Spain, pp. 1175-1181.

24. Saeed AY, Mazin H, Saadi A, Hussein SO (2013) Detection of Escherichia coli O157 in vegetables. IOSR J Agric Vet Sci 6: 16-18.

25. Claus D (1992) A standardized Gram staining procedure. World J Microbiol Biotechnol $8: 451-452$.

26. Bauer A, Kirby W, Sherris J, Turck M (1966) Antibiotic susceptibility testing by a standardized single disk method. Am J Clin Pathol 45:493-496.

27. CLSI (2012) Performance Standards for Antimicrobial Disk Susceptibility Tests; Approved Standard-Eleventh Edition. Vol 32, No.1.

28. Vankerckhoven V, Van Autgaerden T, Vael C, Lammens C, Chapelle S, Rossi R, Jabes D, Goossens H (2004) Development of a Multiplex PCR for the Detection of asa1, gelE, cylA, esp, and hyl Genes in Enterococci and Survey for Virulence Determinants among European Hospital Isolates of Enterococcus faecium. J Clin Microbiol 42: 4473-4479.

29. Bej AK, Dicesare JL, Haff L, Atlas RM (1991) Detection of Escherichia coli and Shigella spp. in Water by Using the Polymerase Chain Reaction and Gene Probes for uid. Appl Environ Microbiol 57: 1013-1017.

30. Horakova K, Mlejnkova H, Mlejnek P (2008) Specific detection of Escherichia coli isolated from water samples using polymerase chain reaction targeting four genes: cytochrome bd complex, lactose permease, b-D-glucuronidase, and b-D-galactosidase. J Appl Microbiol 105: 970-976.

31. Lopez-Saucedo C, Cerna JF, Villegas-Sepulveda N, Thompson R, Velazquez FR, Torres J, Tarr PI, Estrada-García T (2003) Single multiplex polymerase chain reaction to detect diverse loci associated with diarrhoeagenic Escherichia coli. Emerg Infect Dis 9: 127-131.

32. Machado E, Canton R, Baquero F, Galan JC, Rollan A, Peixe L, Coque TM (2005) Integron Content of Extended-Spectrum--Lactamase-Producing Escherichia coli Strains over 12 Years in a Single Hospital in Madrid, Spain. Antimicrob Agents Chemother 49: 18231829.

33. Kargar M, Mohammadalipour Z, Doosti A, Lorzadeh S, Japoni-Nejad A (2014) High Prevalence of Class 1 to 3 Integrons Among Multidrug-Resistant Diarrheagenic Escherichia coli in Southwest of Iran. Osong Public Health Res Perspect 5: 193-198. 
34. Piccirillo A, Giovanardi D, Dotto G, Grilli G, Montesissa, C, Boldrin C, Salata C, Giacomelli M (2014) Antimicrobial resistance and class 1 and 2 integrons in Escherichia coli from meat turkeys in Northern Italy. Avian Pathol 43: 396-405.

35. Vasilakopoulou A, Psichogiou M, Tzouvelekis L, Tassios PT, Kosmidis C, Petrikkos G, Roma ES, Charvalos E, Passiotou M, Avlami A, Daikos GL (2009) Prevalence and characterization of class 1 integrons in Escherichia coli of poultry and human origin. Foodborne Pathog Dis 6: 1211-1218.

36. Chah KF, Agbo IC, Eze DC, Somalo S, Estepa V, Torres C (2010) Antimicrobial resistance, integrons and plasmid replicon typing in multiresistant clinical Escherichia coli strains from Enugu State, Nigeria. J Basic Microbiol 50: S18-S24.

37. Odetoyin BW, Labar AS, Lamikanra A, Aboderin AO, Okeke IN (2017) Class 1 and 2 integrons in faecal Escherichia coli strains isolated from mother-child pairs in Nigeria. PLoS ONE 12: e0183383.

38. Adelowo OO, Helbig T, Knecht C, Reincke F, Mäusezahl I, Müller JA (2018) High abundances of class 1 integrase and sulfonamide resistance genes, and characterisation of class 1 integron gene cassettes in four urban wetlands in Nigeria. PLoS ONE 13: e0208269.

39. Ramírez MS, Pineiro S, Argentinian Integron Study Group, Centron D (2010) Novel Insights about Class 2 Integrons from Experimental and Genomic Epidemiology. Antimicrob Agents Chemother 54: 699-706.

40. Malek MM, Amer FA, Allam AA, El-Sokkary RH, Gheith T, Arafa MA (2015) Occurrence of class I and II integrons in Enterobacteriaceae collected from Zagazig University Hospitals, Egypt. Front Microbiol 6: 601.

41. Pan JC, Ye R, Meng DM, Zhang W, Wang HO. Liu KZ (2006) Molecular characteristics of class 1 and class 2 integrons and their relationships to antibiotic resistance in clinical isolates of Shigella sonnei and Shigella flexneri. J Antimicrob Chemother 58: 288-296.

42. Chigor VN, Umoh VJ, Smith SI, Igbinosa EO, Okoh AI (2010) Multidrug resistance and plasmid patterns of Escherichia coli $\mathrm{O} 157$ and other E. coli isolated from diarrhoeal stools and surface waters from some selected sources in Zaria, Nigeria. Int J Environ Res Public Health 7: 3831-3841.

43. Okeke IN, Lamikanra A, Czeczulin J, Dubovsky F, Kaper JB, Nataro JP (2000b) Heterogeneous Virulence of Enteroaggregative Escherichia coli Strains Isolated from Children in Southwest Nigeria. J Infect Dis 181: 252-260.

44. Smith SI, Bello OS, Goodluck HA, Omonigbehin EA, Agbogu VN, Odeigah P (2009) Prevalence of EHEC O157:H7 from human and environmental samples from Lagos and Zaria. Pakistan J Med Sci 25: 398-403.

45. Titilawo Y, Sibanda T, Obi L, Okoh A (2015a) Multiple antibiotic resistance indexing of Escherichia coli to identify high-risk sources of faecal contamination of water. Environ Sci Pollut Res 22: 10969-10989.

46. Yang Y, Li B, Zou S, Fang HHP, Zhang T (2014) Fate of antibiotic resistance genes in sewage treatment plant revealed by metagenomic approach. Water Res 62: 97-106.

47. Juhas M, Widlake E, Teo J, Huseby DL, Tyrrell JM, Polikanov YS, Ercan O, Petersson A, Cao S, Aboklaish AF, Rominski A, Crich D, Bottger EC, Walsh TR, Hughes D, Hobbie SN (2019) In vitro activity of apramycin against multidrug-, carbapenem- and aminoglycoside-resistant Enterobacteriaceae and Acinetobacter baumannii. J Antimicrob Chemother 74: 944-952. 
Figure 1 
$\begin{array}{llllllllllllllllllll}M & W & 1 & 2 & 3 & 4 & 5 & 6 & 7 & 8 & M & W & 9 & 10 & 11 & 12 & 13 & 14 & 15 & M\end{array}$

436 bp

788 bp

436 bp

Figure 2 